\title{
КОНЦЕПЦІЯ УПРАВЛІННЯ СОЦІАЛЬНИМ КАПІТАЛОМ ПІДПРИЄМСТВА В КОНТЕКСТІ ЗАБЕЗПЕЧЕННЯ ЙОГО КОНКУРЕНТОСПРОМОЖНОСТІ
}

\section{THE CONCEPT OF ENTERPRISE'S SOCIAL CAPITAL MANAGEMENT IN THE CONTEXT OF ENSURING ITS COMPETITIVENESS}

\author{
Кроль Віта Вікторівна \\ асистентка, \\ Національний університет водного господарства та природокористування \\ ORCID: https://orcid.org/0000-0002-7835-6248
}

Krol Vita
National University of Water and Environmental Engineering

У статті розглянуто соціальний капітал підприємства в контексті підвищення конкурентоспроможності. На основі узагальнення теоретичних підходів до оцінки впливу соціального капіталу підприємств визначено, що найбільші можливості для комплексного оцінювання соціального капіталу в розрізі факторів забезпечує підхід на основі його декомпозиції на три складові: структурний, реляційний, когнітивний соціальний капітал. Обґрунтовано доцільність імплементації управління соціальним капіталом в управління конкурентоспроможністю підприємств. У зв'язку з цим запропоновано схему процесу імплементації з деталізацією змісту та послідовності загальних фрункцій управління соціальним капіталом.

Ключові слова: соціальний капітал підприємства, конкурентоспроможність, структурний соціальний капітал, реляційний соціальний капітал, когнітивний соціальний капітал.

В статье рассмотрен социальный капитал предприятия в контексте повышения его конкурентоспособности. На основе обобщения теоретических подходов к оценке влияния социального капитала предприятий определено, что наибольшие возможности для комплексной оценки социального капитала в разрезе фракторов обеспечивает подход на основе его декомпозиции на три составляющие: структурный, реляционный, когнитивный социальный капитал. Обоснована целесообразность имплементации управления социальным капиталом в управление конкурентоспособностью предприятий. В этой связи предложена схема процесса имплементации с детализацией содержания и последовательности общих фрункций управления социальным капиталом.

Ключевые слова: социальный капитал предприятия, конкурентоспособность, структурный социальный капитал, реляционный социальный капитал, когнитивный социальный капитал.

The social capital of the enterprise in the context of increase of competitiveness is considered in the article. It is investigated that thriving development of the social capital researches is determined by the need to enhance competitiveness due to the influence of intangible factors. It is especially important in the modern world in terms of economic instability, large-scale crisis, political pressure and gaps in economic development. The social capital at different levels of relations is seen now as a constituent of business processes stability and source of competitive advantages. Consequently, ensuring the strategic management of enterprises competitiveness requires the creation of business environment contributing not only to economic success but also to development of social capital. However, studies on the impact of social capital on the competitiveness of enterprises need further development in order to find the most relevant factors of the social capital influencing the economic successes of business entities. In this regard it is important to develop also the conceptual basis for managing the social capital of the enterprise by its implementation in the process of competitiveness management. In this study the approach to achieve this goal is proposed using a set of general and special principles, methods, including generalization, comparison, analysis and synthesis. The implementation of the social capital management in the practice of competitiveness management can provide positive links with consumers, employees, local communities, which forms the positive future prospective for business activity. In order to ensure competitiveness, it is required to consider the management of social capital as a business process with definition of its stages and directions by key dimensions - structural, relational and cognitive strategic directions for the development of components of social capital. It requires the identification of key activities within the stages of social capital management. The principal recommendations of these activities content and coherence are proposed in this study.

Keywords: social capital, competitiveness, structural social capital, relational social capital, cognitive social capital. 
Постановка проблеми. Забезпечення стратегічної конкурентоспроможності сучасних підприємств вимагає створення середовища, яке б не лише сприяло економічним успіхам, а й забезпечувало розвиток соціального капіталу. Негативні тенденції, що демонструють рейтинги індексів людського розвитку, глобальної конкурентоспроможності економіки України підкреслюють необхідність та доцільність врахування та оцінки соціального капіталу як важливого елементу економічного розвитку сучасних підприємств.

Аналіз останніх досліджень і публікацій. Дослідження соціального капіталу до останнього часу проводилися в основному на макрорівні шляхом вимірювання рівня довіри членів суспільства один до одного і до інститутів влади. На цій основі робився висновок про ступінь розвиненості соціального капіталу в суспільстві в цілому. Аналіз наукової літератури 3 даної тематики показав, що 3 проблем дослідження соціального капіталу тільки в нашій країні протягом останніх п'яти років написано понад 3500 наукових робіт.

В останні роки науковці звернули увагу на вивчення соціального капіталу організацій, оскільки саме там, в первинному осередку сучасного суспільства, фрормується не тільки фрінансовий, але соціальний капітал.

Так, Гриненко А.М., Кирилюк В.В. в своїй праці обґрунтували ключову роль соціального капіталу у процесах економічної та фрінансової ефективності українських бізнес-організацій [2]. Бойко М.М. у своїй праці запропонувала стратегічний підхід до формування та використання соціального капіталу у ссрері послуг як основи конкурентних переваг [1]. Дем'яненко Ю.В. пропонує концепцію моделювання процесів фрормування та використання соціального капіталу підприємств сорери послуг, яка враховує особливості формування соціального капіталу, як приватного активу підприємства ссрери послуг 3 метою його подальшого використання в економічній діяльності цих підприємств [3].

Отож, на сьогодні $€$ досить обширна база досліджень соціального капіталу підприємств, що дозволяють враховувати різноманіття охоплених цим поняттям взаємин шляхом розробки методів комплексного вимірювання соціального капіталу на рівні організації. Проте тематика управління соціальним капіталом підприємства в контексті забезпечення його конкурентоспроможності не $€$ достатньо вивченою та потребує подальших досліджень.
Формулювання цілей статті (постановка завдання). Метою статті $є$ дослідження соціального капіталу підприємства та розробка концептуальних засад управління ним в контексті підвищення конкурентоспроможності. Для досягнення цієї мети сорормульовано наступні завдання:

- систематизувати результати емпіричних досліджень щодо впливу соціального капіталу на економічні показники;

- сорормувати концептуальні основи управління соціальним капіталом підприємства шляхом його імплементації в практику управління конкурентоспроможністю підприємств.

Виклад основного матеріалу дослідження. Попри всю неоднозначність підходів до аналізу концепції соціального капіталу, на сьогодні фрактично всі дослідники визнають, що соціальний капітал та його компоненти $\epsilon$ важливими у підприємництві. При цьому за найбільш визнаним на сьогодні $є$ підхід, згідно з яким основними компонентами соціального капіталу є:

- структурний;

- пізнавальний (когнітивний);

- реляційний [4].

Найпоширенішим та прийнятним для розуміння соціального капіталу $€$ розмежування між структурним, когнітивним та реляційним соціальним капіталом, що вперше розробили Nahapiet \& Ghoshal [14]. Саме цю концепцію покладено в основу розробки власного оцінювання соціального капіталу підприємства з точки зору впливу його на конкурентоспроможність підприємства (рис. 1).

Результати аналізу емпіричних досліджень вчених та дослідників підтверджують теоретичні пояснення взаємозв'язків між соціальним капіталом та економічними показниками. Так, соціальний капітал впливає на економічні показники шляхом:

- Зменшення трансакційних витрат - соціальні норми можуть працювати, щоб зменшити «трансакційні витрати», породжуючи нефрормальні правила та спільне розуміння, які дозволяють людям ефективно вести свою особисту взаємодію та ділові відносини. Зменшення трансакційних витрат таким чином має вирішальне значення для ефективного фрункціонування сучасної економіки [8; 14] та оптимізації розміру організації для максимальної есрективності [9].

- Зниження невизначеності - довіра в соціальних мережах служить заміною правовій системі; коли менше ресурсів потрібно вико- 




Рис. 1. Структура соціального капіталу підприємства

Джерело: розроблено автором

ристовувати для захисту окремих осіб та фрірм від крадіжок та інших нечесних дій, більше ресурсів можна виділити на виробництво та вдосконалення технологій [10]. Це також означає, що інвестиційні рішення можна приймати 3 використанням більш тривалого часового горизонту, і можна інвестувати у ризикованіші, але з часом більш продуктивні проекти [12].

- Сприяння поширенню інформації, знань та інновацій - не лише серед працівників однієї фрірми, а також через профресійні мережі та стосунки 3 друзями та колишніми колегами; це допомагає використовувати різні ресурси компанії, включаючи нематеріальні, такі як інтелектуальний капітал [6]. Ці зв'язки дозволяють знизити вартість та час пошуку та обміну інсрормацією та впроваджувати інновації раніше. У цьому сенсі соціальний капітал також сприяє поглинаючій здатності економіки, що дуже важливо для продуктивності [12].

- Сприяння кооперативній та/або соціально налаштованій поведінці - соціальний капітал сприяє еорективності, дозволяючи співпрацювати між людьми 3 конорліктними інтересами для досягнення збільшення виробництва, а також дозволяє більш ефективно використовувати ресурси та справедливо розподіляти [7; 5; 13]. В організаціях культура відкритості та довіри на робочому місці може сприяти співпраці та обміну інсрормацією між персоналом, а отже, досягненню корпоративних цілей. Така культура може переважати над вузькими інтересами кожного співробітника, що може полягати в тому, щоб приховувати інформацію від колег, які часто $€$ потенційними конкурентами для просування по службі, або іншими, котрі мають перевагу в цій організації. Стверджується, що мережі мають синергетичний ефект, об'єднуючи навички та різні ідеї, які можуть призвести до радикальних проривів, значно покращивши продуктивність [11]. Соціальний капітал підвищує продуктивність та розвиток цінності в командах, забезпечуючи співпрацю між членами команди за допомогою віртуального або віч-на-віч контакту [15]. 
Враховуючи зазначені вище результати теоретичних досліджень, можна зробити висновок, що проблеми розвитку та управління соціальним капіталом підприємства $€$ актуальними та за змістом $є$ складними процесами, які не можна зводити до довіри, норм та цінностей. Тому до управління соціальним капіталом варто використовувати ресурсний, стратегічний, організаційний та системний підходи.

Управління соціальним капіталом підприємств може бути ефективним лише за умови, що він сприймається не лише як ресурс (тобто щось, що можна використати), а справді як капітал - цінність, що має приносити дохід, але для цього потрібно забезпечувати відповідні умови для підтримки, збереження та по можливості - розвитку. Відмінністю управління соціальним капіталом від інших типів капіталу виступають особливості взаємодії суб'єктів в процесі відтворення. Відтворення соціального капіталу пов'язане 3 економічними відносинами, що виникають як результат використання соціальних зв'язків, якими володіє

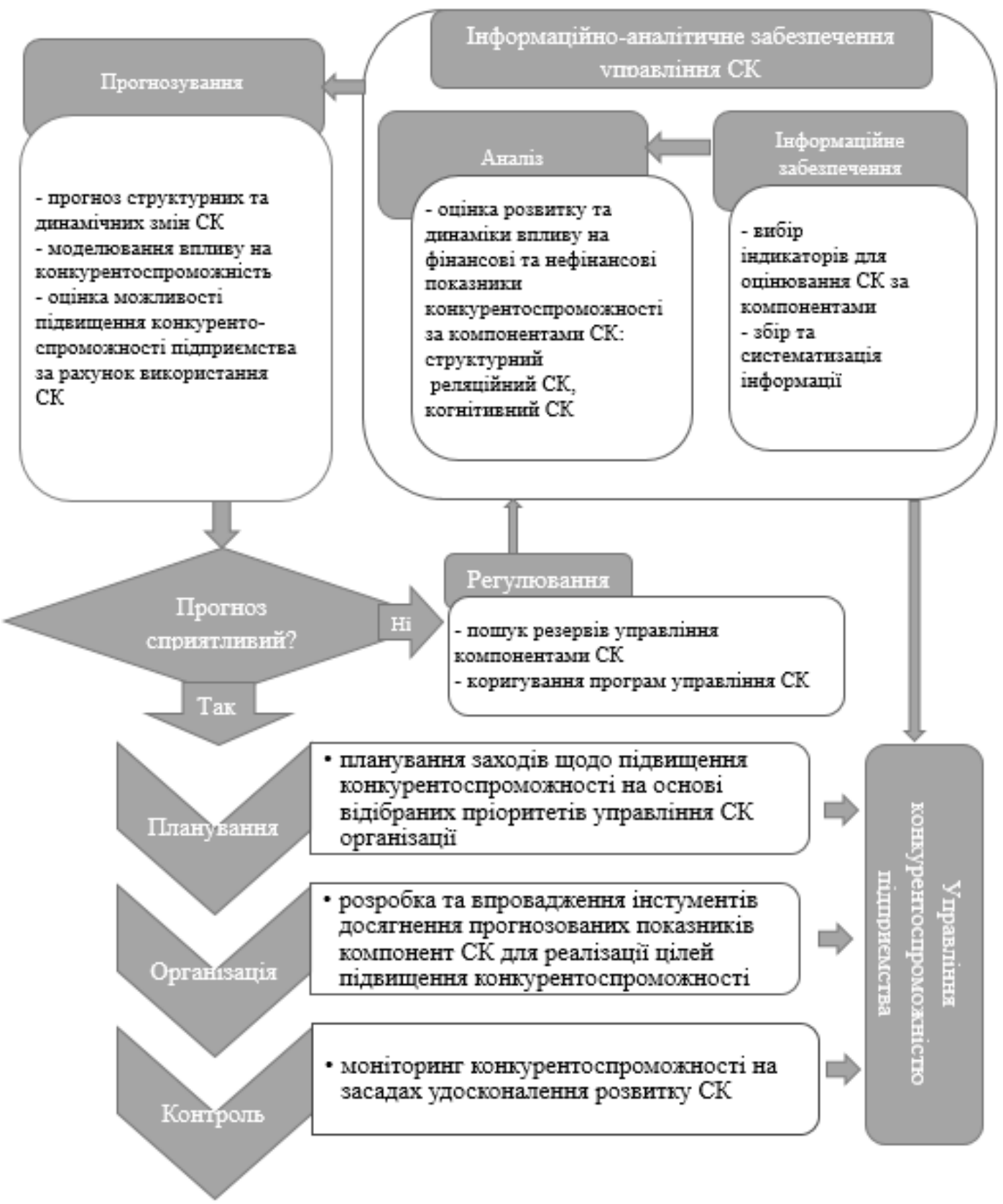

Рис. 2. Схема імплементації соціального капіталу в практику управління конкурентоспроможністю підприємства 
економічний агент. Позитивний економічний результат супроводжується закріпленням i розвитком вже існуючих соціальних зв'язків.

Процес управління розвитком соціального капіталу підприємств в контексті підвищення його конкурентоспроможності в сучасних економічних умовах передбачає інтеграцію відповідних дій в стратегію його діяльності. Імплементація концепції соціального капіталу в практику управління конкурентоспроможністю підприємств з урахуванням методологічних засад теорії менеджменту, може бути такою, як наведено на рис. 2.

Імплементація теорії соціального капіталу в практику управління конкурентоспроможністю забезпечує позитивні зв'язки з споживачами, найманими працівниками, місцевими громадами, що фрормує і майбутні перспективи успіхів бізнесу в регіоні його діяльності.

Висновки. Управління соціальним капіталом підприємства в контексті підвищення його конкурентоспроможності передбачає фрормування стратегічних напрямів розвитку компонент соці- ального капіталу та потребує поетапного підходу до ідентифрікації ключових здібностей та ресурсів в розрізі структурного, реляційного та когнітивного вимірів. Стратегічні напрями формування та розвитку компонент соціального капіталу повинні бути чітко взаємопов'язані та взаємозумовлені цілями конкурентної стратегії підприємства, а також визначати:

- формування траєкторій розвитку компонент соціального капіталу;

- вибір технологій та інструментарію фрормування та розвитку компонент соціального капіталу;

- взаємозв'язок стратегічних напрямів формування та розвитку структурного, реляційного та когнітивного соціального капіталу із цілями діяльності підприємства;

- способи ресурсного забезпечення фрормування та розвитку соціального капіталу.

При цьому вибір стратегічних напрямів формування та розвитку компонент соціального капіталу здійснюється на основі процесів конорігурації та реконсрігурації можливостей підприємства.

\section{СПИСОК ВИКОРИСТАНИХ ДЖЕРЕЛ:}

1. Бойко М.М. Соціальний капітал як чинник конкурентоспроможності підприємств сфрери послуг. Теоретичні та прикладні питання економіки. 2014. № 1. C. 486-495. URL: http://www.tppe.econom.univ.kiev.ua/ data/2014_28_2/zb28_2_43.pdf

2. Гриненко А.М., Кирилюк В.В. Соціальний капітал бізнес-організацій: сучасні тренди та тенденції. Social and Labour Relations: Theory and Practice. 2019. № 9. URL: https://ir.kneu.edu.ua:443/handle/2010/34127

3. Дем'яненко Ю.В. Обґрунтування концепції моделювання соціального капіталу підприємств ссери послуг. Ефективна економіка. 2012. № 10. URL: http://www.economy.nayka.com.ua/?op=1\&z=1452

4. Кроль В.В. Концептуальні засади аналізу соціального капіталу. Вісник Національного університету водного господарства та природокористування. Економічні науки. 2018. Вип. 2. С. 110-116. URL: http://nbuv.gov.ua/UJRN/Vnuvgp_ekon_2018_2_14

5. Arrow K.J. Observations on social capital. In Social Capital: A Multifaceted Perspective. Dasgupta, P., Seregeldin, I., Eds. The World Bank: Washington, USA. 2000. P. 3-5. URL: https://www.researchgate.net/ publication/285136629_Observations_on_Social_Capital_In_Social_Capital_A_Multifaceted_Perspective

6. Beugelsdijk S.,Van Schaik, T. Social capital and growth in European regions: An empirical test. European Journal of Political Economy. 2005. № 21. P. 301-324. URL: https://www.researchgate.net/publication/222431176_ Social_capital_and_growth_in_European_regions_An_empirical_test

7. Brown L.D., Ashman D. Participation, social capital, and intersectoral problem solving: African and Asian cases. World Development. 1996. № 24. P. 1467-1479. URL: https://www.researchgate.net/publication/223827804_ Participation_Social_Capital_and_Intersectoral_Problem_Solving_African_and_Asian_Cases

8. Fukuyama F. Social capital, civil society and development. Third World Quarterly. 2001. № 22. P. 7-20. URL: https://www.jstor.org/stable/3993342

9. Fukuyama, F. Trust: Social Virtues and the Creation of Prosperity; Free Press: New York, NY, USA, 1995. URL: https://www.jstor.org/stable/20752121

10. Jankauskas V., Šeputiene J. The relation between social capital, governance and economic performance in Europe. Bus. Theory Pract. 2007. № 8. P. 131-138. URL: https://www.researchgate.net/publication/228932447_ The_Relation_between_Social_Capital_Governance_and_Economic_Performance_in_Europe

11. Kaasa A. Effects of different dimensions of social capital on innovative activity: Evidence from Europe at the regional level. Technovation. 2009. № 29. P. 218-233. URL:https://www.researchgate.net/publication/245131733_ Effects_of_different_dimensions_of_social_capital_on_innovative_activity_Evidence_from_Europe_at_the_ regional_level 
12. Kaasa A. Social Capital, Institutional Quality and Productivity: Evidence from European Regions. Economics and Sociology. 2016. № 9. P. 11-26. URL: https://www.researchgate.net/publication/322707257_Social_Capital_ Institutional_Quality_and_Productivity_Evidence_from_European_Regions

13. Knack S., Keefer, P. Does social capital have an economic payoff? A cross-country investigation. The Quarterly Journal of Economics. 1997. № 112. P. 1251-1288. URL: https://www.jstor.org/stable/2951271

14. Nahapiet J., Ghoshal S. Social Capital, Intellectual Capital, and the Organizational Advantage. The Academy of Management Review. 1998. № 23. P. 242-266. URL: https://www.jstor.org/stable/259373

15. Sözbilir F. The interaction between social capital, creativity and efficiency in organisations. Think. Skills Creat. 2018. № 27. P. 92-100. https://www.researchgate.net/publication/322039512_The_interaction_between_social_ capital_creativity_and_efficiency_in_organizations

\section{REFERENCES:}

1. Boiko M.M. (2014) Sotsialnyi kapital yak chynnyk konkurentospromozhnosti pidpryiemstv sfery posluh. Teoretychni ta prykladni pytannia ekonomiky, no. 1, pp. 486-495. Retrieved from: http://www.tppe.econom.univ.kiev.ual data/2014_28_2/zb28_2_43.pdf

2. Hrynenko A.M., Kyryliuk V.V. (2019) Sotsialnyi kapital biznes-orhanizatsii: suchasni trendy ta tendentsii. Social and Labour Relations: Theory and Practice, no. 9. Retrieved from: https://ir.kneu.edu.ua:443/handle/2010/34127

3. Demianenko Yu.V. (2012) Obgruntuvannia kontseptsii modeliuvannia sotsialnoho kapitalu pidpryiemstv sfery posluh. Efektyvna ekonomika, no. 10. Retrieved from: http://www.economy.nayka.com.ua/?op=1\&z=1452

4. Krol V.V. (2018) Kontseptualni zasady analizu sotsialnoho kapitalu. Visnyk Natsionalnoho universytetu vodnoho hospodarstva ta pryrodokorystuvannia. Ekonomichni nauky, vol. 2, pp. 110-116. Retrieved from: http://nbuv.gov.ua/UJRN/Vnuvgp_ekon_2018_2_14

5. Arrow K.J. (2000) Observations on social capital. In Social Capital: A Multifaceted Perspective. Dasgupta, P., Seregeldin, I., Eds. The World Bank: Washington, USA, pp. 3-5. Retrieved from: https://www.researchgate.net/ publication/285136629_Observations_on_Social_Capital_In_Social_Capital_A_Multifaceted_Perspective

6. Beugelsdijk S., Van Schaik, T. (2005) Social capital and growth in European regions: An empirical test. European Journal of Political Economy, no. 21, pp. 301-324. Retrieved from: https://www.researchgate.net/publication/222431176_Social_capital_and_growth_in_European_regions_An_empirical_test

7. Brown L.D.; Ashman D. (1996) Participation, social capital, and intersectoral problem solving: African and Asian cases. World Development, no. 24, pp. 1467-1479. Retrieved from: https://www.researchgate.net/publication/223827804_Participation_Social_Capital_and_Intersectoral_Problem_Solving_African_and_Asian_Cases

8. Fukuyama F. (2001) Social capital, civil society and development. Third World Quarterly, no. 22, pp. 7-20. Retrieved from: https://www.jstor.org/stable/3993342

9. Fukuyama, F. (1995) Trust: Social Virtues and the Creation of Prosperity; Free Press: New York, NY, USA. Retrieved from: https://www.jstor.org/stable/20752121

10. Jankauskas V., Šeputiene J. (2007) The relation between social capital, governance and economic performance in Europe. Bus. Theory Pract., no. 8, pp. 131-138. Retrieved from: https://www.researchgate.net/publication/228932447_The_Relation_between_Social_Capital_Governance_and_Economic_Performance_in_Europe

11. Kaasa A. (2009) Effects of different dimensions of social capital on innovative activity: Evidence from Europe at the regional level. Technovation, no. 29, pp. 218-233. Retrieved from: https://www.researchgate.net/publication/245131733_Effects_of_different_dimensions_of_social_capital_on_innovative_activity_Evidence_from_ Europe_at_the_regional_level

12. Kaasa A. (2016) Social Capital, Institutional Quality and Productivity: Evidence from European Regions. Economics and Sociology, no. 9, pp. 11-26. Retrieved from: https://www.researchgate.net/publication/322707257_ Social_Capital_Institutional_Quality_and_Productivity_Evidence_from_European_Regions

13. Knack S., Keefer, P. (1997) Does social capital have an economic payoff? A cross-country investigation. The Quarterly Journal of Economics, no. 112, pp. 1251-1288. Retrieved from: https://www.jstor.org/stable/2951271

14. Nahapiet J., Ghoshal S. (1998) Social Capital, Intellectual Capital, and the Organizational Advantage. The Academy of Management Review, no. 23, pp. 242-266. Retrieved from: https://www.jstor.org/stable/259373

15. Sözbilir F. (2018) The interaction between social capital, creativity and efficiency in organisations. Think. Skills Creat., no. 27, pp. 92-100. Retrieved from: https://www.researchgate.net/publication/322039512_The_interaction_between_social_capital_creativity_and_efficiency_in_organizations 